\title{
A Field Experimental Study of Composite Foundation with CFG Pile + Vibro-replacement Stone Column Pile in Liquefaction Area
}

\author{
Ming Zhang ${ }^{1, a, *} ;$ Xianfeng Zhang ${ }^{1, b}$ \\ ${ }^{1}$ Henan Electric Power Survey and Design Institute, Henan, China \\ azhangming-heny@powerchina.cn, bzhangxianfeng-heny@powerchina.cn, \\ ${ }^{*}$ Corresponding author
}

Key words: silt, liquefaction, foundation treatment, CFG pile, vibro-replacement stone column pile

Abstract: Silt foundation in Kaifeng area was select as the research object, to verification the combination of foundation treatment for CFG pile + vibro-replacement stone column pile methods. The results showed that: engineering properties of the foundation soil between piles are improved after the CFG pile or vibro-replacement stone column composite foundation. More important, the liquefaction of silt foundation can be eliminated by treatment with CFG pile + vibro-replacement stone column pile. The foundation bearing capacity values were improved from $75 \mathrm{kPa}$ (soil between piles) to $300 \mathrm{kPa}$ (composite foundation), which meet the load requirements.

\section{Introduction}

Liquefaction occurs in saturated silt ground in the case of seismic, leading to the loss of carrying capacity, a greater differential settlement, moreover, causing buildings to crack, tilt and destruction. Common ground liquefaction eliminates method are compaction method (vibroflotation method, vibrating chip pile, vibrating pressing sandstone pile and Dynamic compaction method, etc.) and replacement method ${ }^{[1][2]}$. When the engineering properties of liquefaction ground are poor, the mentioned methods above are not enough. based on the principle that bearing capacity of foundation treatment by CFG pile can be increased, and liquefaction can be eliminated by treatment with vibro-replacement stone column pile, the paper proposes the use of foundation treatment methods by CFG pile + vibro-replacement stone column pile. The static loading tests were done to verify the effect of foundation treatmen, providing reliable test data for the study of liquefaction soil foundation with low carrying capacity.

\section{Test Site}

Test site belongs to the Yellow River alluvial plain, the topography is flat and the terrain is open (Fig.1). Geotechnical engineering investigation results indicate that the foundation soil is mainly composed of silt, silty clay and fine sand. The foundation soil belongs to Liquefied soil. The exposed strata in geotechnical exploration depth are divided into ten layers, as shown in Table 1.

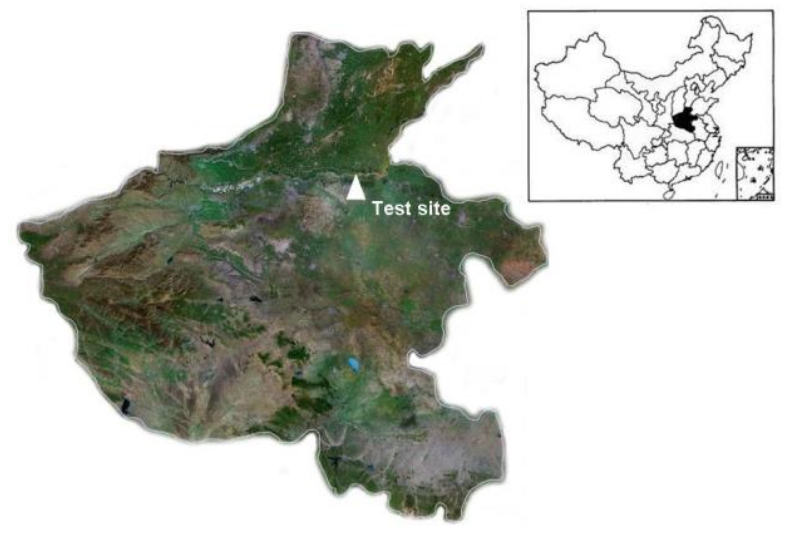

Fig.1 Test site 
Table 1 Physical and engineering property Indexes of exposed strata in the test site

\begin{tabular}{|c|c|c|c|c|c|c|c|c|c|}
\hline $\begin{array}{l}\text { Strata } \\
\text { No. } \\
\text { and } \\
\text { litholo } \\
\text { gic }\end{array}$ & $\begin{array}{c}\text { Strata } \\
\text { thickne } \\
\quad \text { ss } \\
\\
{[\mathrm{m}]}\end{array}$ & $\begin{array}{c}\text { Moist } \\
\text { unit } \\
\text { weight } \\
{\left[\mathrm{kN} / \mathrm{m}^{3}\right.} \\
]\end{array}$ & $\begin{array}{c}\text { Dry } \\
\text { unit } \\
\text { weight } \\
{[\mathrm{kN} / \mathrm{m}} \\
3]\end{array}$ & $\begin{array}{c}\text { Voi } \\
\mathrm{d} \\
\text { rati } \\
\mathrm{o}\end{array}$ & $\begin{array}{l}\quad \text { liqu } \\
\text { idity } \\
\text { index }\end{array}$ & $\begin{array}{l}\text { modulus } \\
\text { of } \\
\text { compressi } \\
\text { on }\end{array}$ & $\begin{array}{l}\text { Cohe } \\
\text { sion } \\
{[\mathrm{kPa}]}\end{array}$ & $\begin{array}{l}\text { Fricti } \\
\text { on } \\
\text { angle } \\
{[0]}\end{array}$ & $\begin{array}{c}\text { Characteristic } \\
\text { value of subsoil } \\
\text { bearing } \\
\text { capacity } \\
{[\mathrm{kPa}]}\end{array}$ \\
\hline (1) silt & 1.6 & 19.1 & 15.1 & $\begin{array}{c}0.79 \\
3\end{array}$ & I & 5.0 & 5 & 10.0 & 95 \\
\hline $\begin{array}{l}\text { (2) silty } \\
\text { clay }\end{array}$ & 2.3 & 19.6 & 15.2 & $\begin{array}{c}0.79 \\
4\end{array}$ & 0.93 & 3.8 & 6 & 8.0 & 75 \\
\hline (3) silt & 1.4 & 19.3 & 14.7 & $\begin{array}{c}0.84 \\
4\end{array}$ & I & 5.7 & 11 & 24.5 & 105 \\
\hline $\begin{array}{l}\text { (4) silty } \\
\text { clay }\end{array}$ & 2.3 & 19.3 & 14.9 & $\begin{array}{c}0.82 \\
7\end{array}$ & 1.04 & 3.9 & 7 & 10.0 & 85 \\
\hline (5) silt & 7 & 19.5 & 15.2 & $\begin{array}{c}0.77 \\
1\end{array}$ & I & 7.3 & 10 & 17.5 & 120 \\
\hline (6) silt & 2.3 & 19.6 & 15.6 & $\begin{array}{c}0.74 \\
4\end{array}$ & I & 3.4 & I & I & 75 \\
\hline (7) silt & 2.0 & 19.7 & 15.8 & $\begin{array}{c}0.70 \\
7\end{array}$ & I & 8.5 & I & I & 160 \\
\hline (8) silt & 4.0 & 20.6 & 16.9 & $\begin{array}{c}0.90 \\
0\end{array}$ & I & 3.0 & I & I & 70 \\
\hline
\end{tabular}

\section{Test Design}

The plane size is $8.63 \mathrm{~m} \times 5.91 \mathrm{~m}$, including three rows of Cement Fly-ash Grave (CFG) piles and four rows of Dry Vibro-Crushed Stone Pile, which were interlaced and normal arrangement, pile spacing is $1.45 \mathrm{~m}$. there were two rows of dry Vibro-Crushed Stone Pile at each outside. The CFG pile is $\mathrm{C} 25$, diameter is $500 \mathrm{~mm}$, effective length is $19.8 \mathrm{~m}$. Pile top located under the natural ground about $2.0 \mathrm{~m}$ (layer(2) silty clay) and pile tip located under the layer(10) fine sand. The diameter of Dry Vibro-Crushed Stone Pile is $500 \mathrm{~mm}$, effective length is $16.5 \mathrm{~m}$ and the pile top located under the natural ground about $2.0 \mathrm{~m}$ (layer(2) silty clay).

The plane size of the second one is $9.60 \times 6.56 \mathrm{~m}$, pile spacing is $1.40 \mathrm{~m}$. the two programs are six rows of 33 rammed soil-cement piles, arranged in equilateral triangle. The pile diameter is 500 $\mathrm{mm}$, effective length is $10.0 \mathrm{~m}$ (in layer(5) greater than $1.0 \mathrm{~m}$ ), and the cushion thickness on the top is $300 \mathrm{~mm}$. The pile material is the cement-soil mixture. The compressive strength average value of the pile material block (cube of length $150 \mathrm{~mm}$ ), standard curing 28 days, is not less than 10.0 MPa. The $t$ ratio of dry weigh for cement and soil is 1:5.

The water table was lowered by small tube wells before static loading test, the test plane is under natural ground about $3.3 \mathrm{~m}$.

\section{Liquefaction Analysis}

The standard penetration test and grain size test were used to analysis the soil liquefaction of composite foundation, based on the same criterion condition to the soil before treatment. The Standard Penetration Number increases obviously to soil between piles in the test area. According to the discrimintant analysis, the soil liquefaction were basically eliminated except for the depth range $13.00-14.00 \mathrm{~m}$, the thickness of liquefied soil layer is $0.50-0.90 \mathrm{~m}$. the detailed discrimintant result of liquefaction lever for soil between piles is showed in table 2. 
Table 2 the detailed discrimintant result of liquefaction lever for soil between piles

\begin{tabular}{|c|c|c|c|c|c|c|c|}
\hline Position & $\begin{array}{l}\text { Depth } \\
\text { (m) }\end{array}$ & $\mathrm{Ni}$ & Ncri & $\begin{array}{l}\text { liquefaction } \\
\text { result }\end{array}$ & $\begin{array}{l}\text { thickness of } \\
\text { liquefied soil } \\
\text { (m) }\end{array}$ & $\mathrm{I}_{\mathrm{IEi} 15 \mathrm{~m}}$ & $\mathrm{I}_{\mathrm{IE} 15 \mathrm{~m}}$ \\
\hline \multirow{12}{*}{ B1 } & 3.45 & 14 & 5.3 & Non & & & \multirow{11}{*}{0.5} \\
\hline & 4.45 & 16 & 4.6 & Non & & & \\
\hline & 5.45 & 12 & 4.5 & Non & & & \\
\hline & 6.45 & 9 & / & Non & & & \\
\hline & 7.45 & 33 & 5.3 & Non & & & \\
\hline & 8.45 & 34 & 8.1 & Non & & & \\
\hline & 9.45 & 12 & / & Non & & & \\
\hline & 10.45 & 19 & I & Non & & & \\
\hline & 11.45 & 24 & 11.6 & Non & & & \\
\hline & 12.45 & 24 & 11.8 & Non & & & \\
\hline & 13.45 & 7 & 10.8 & Yes & $13.1-14.0$ & 0.46 & \\
\hline & 14.45 & 17 & 9.3 & Non & & & \multirow{12}{*}{0.1} \\
\hline \multirow{11}{*}{ B2 } & 3.45 & 8 & 4.3 & Non & & & \\
\hline & 4.45 & 9 & 7.4 & Non & & & \\
\hline & 5.45 & 7 & / & Non & & & \\
\hline & 6.45 & 18 & 8.2 & Non & & & \\
\hline & 7.45 & 20 & 5.7 & Non & & & \\
\hline & 8.45 & 10 & 7.3 & Non & & & \\
\hline & 9.45 & 8 & I & Non & & & \\
\hline & 10.45 & 23 & I & Non & & & \\
\hline & 11.45 & 20 & 11.6 & Non & & & \\
\hline & 12.45 & 11 & I & Non & & & \\
\hline & 13.45 & 6 & 7.1 & Yes & $13.0-13.5$ & 0.13 & \\
\hline \multirow{13}{*}{ B3 } & 14.45 & 18 & 7.5 & Non & & & \multirow{13}{*}{0.0} \\
\hline & 3.45 & 10 & 4.6 & Non & & & \\
\hline & 4.45 & 14 & 4.1 & Non & & & \\
\hline & 5.45 & 11 & 4.7 & Non & & & \\
\hline & 7.45 & 13 & I & Non & & & \\
\hline & 8.45 & 18 & 9.8 & Non & & & \\
\hline & 9.45 & 10 & / & Non & & & \\
\hline & 10.45 & 21 & I & Non & & & \\
\hline & 11.45 & 32 & 7.9 & Non & & & \\
\hline & 12.45 & 14 & 12.2 & Non & & & \\
\hline & 13.45 & 6 & / & Non & & & \\
\hline & 14.45 & 12 & 7.5 & Non & & & \\
\hline & 15.45 & 19 & 9.4 & Non & & & \\
\hline
\end{tabular}

\section{Bearing Capacity}

5.1 Bearing Capacity of Soil Between Piles. Three groups of static loading test for soil between piles were measured, following code for design of building foundation in China ${ }^{[3]}$. All " $p-s$ "curves are slow change curve, without significant proportion boundary point. Experimental condition for the termination is that the ratio of measured collapse and load-bearing plate diameter equal to 0.15 . 
The characteristic values of subsoil bearing capacity of soil between piles in the test is $75 \mathrm{kPa}$.

After the foundation treatment, the in-situ testing index values (SPT blow count, tip resistance and shaft resistance) of soil between piles were significantly increased, the increscent multiple is about 1.32 - 7.65. Judging from the general trend, the increasing in-situ testing index values reflected that the soil between piles was compacted and the Strength was improved obviously. Besides, the strength of different part in soil is more uniform. The liquefaction of loess foundation can be basically eliminated. However, the compaction effect slightly worse in local area, lead to increasing less for the strength, and the liquefaction did not eliminate completely (Table 2).

5.2 CFG Pile. Three groups of static loading test for CFG piles were measured, following technical code for testing of building foundation piles in China ${ }^{[4]}$. Experimental condition for the termination is to meet the design load, and the maximum settlement is $8.6 \mathrm{~mm}$. All " $p$ - s"curves are slow change curve, without significant proportion boundary point. The Ultimately Bearing Capacity of Single Pile is $2000 \mathrm{kN}$.

5.3 Vibro-replacement Stone Column Pile. Three groups of static loading test for vibro-replacement stone column piles were measured, following Technical code for vibroflotation method ground treatment of fossil fuel power plant in China ${ }^{[5]}$. Experimental condition for the termination is that the measured collapse greater than $67.9 \mathrm{~mm}$. All " $p$ - s"curves are slow change curve, without significant proportion boundary point. The Ultimately Bearing Capacity of Single Pile is $318 \mathrm{kN}$.

5.4 Composite Foundation with CFG Pile + Vibro-replacement Stone Column Pile. Three groups of static loading test for composite foundation were measured, following technical code for testing of building foundation piles in China. Experimental condition for the termination is that the ratio of measured collapse and load-bearing plate diameter greater than or equal to 0.06 . All " $p$ $\mathrm{s}$ "curves are slow change curve, without significant proportion boundary point. The Ultimately Bearing Capacity of Single Pile is $300 \mathrm{kN}$.

\section{Conclusions}

Engineering properties of composite foundation with CFG pile + vibro-replacement stone column pile in liquefaction area were measured by field static loading test, and the treatment effect was analysis. It is conclusion that:

(1) After treatment, the soil between piles was compacted and the Strength was improved obviously. Besides, the strength of different part in soil is more uniform. The liquefaction of loess foundation can be basically eliminated.

(2) After treatment, the foundation bearing capacity values were improved from $75 \mathrm{kPa}$ (soil between piles) to $300 \mathrm{kPa}$ (composite foundation), which meet the load requirements.

\section{References}

[1] Chang Shi Biao, etc. Engineering Geology Manual (fourth edition) [M]. Beijing: China building Industry Press, 2012.

[2] Singh, S. Liquefaction characteristics of silts[J]. Geotechnical and Geological engineering, 1996, 14: 1-19.

[3] MOHURD. Code for design of building foundation[S]. Beijing: China architecture and building press, 2012.

[4] MOHURD. Technical code for testing of building foundation piles[S]. Beijing: China architecture and building press, 2012.

[5] The State Economic and Trade Commission. Technical code for vibroflotation method ground treatment of fossil fuel power plant[S]. Beijing: China Electric Power Press, 1999. 